\title{
A Peace Paradigm in Social Work
}

\author{
Adenike Yesufu MacEwan College
}

\begin{abstract}
Résumé
Le travail social est généralement perçu comme une profession dont l'optique est très centralisée. Il est également éclectique en ce que son cadre de travail emprunte à diverses disciplines, ce qui provoque parfois une décentralisation des diverses dimensions de sa pratique et une absence de cohésion. Plusieurs appels ont été lancés pour enrichir le paradigme du travail social. Cet essai jette un regard critique sur la profession et se range du côté des nombreuses demandes qui ont été formulées pour l'élargissement du concept de travail social. Cet article met surtout de l'avant un paradigme de paix qui intégrerait avant tout les enjeux et les perspectives de paix dans les pratiques du travail social.
\end{abstract}

\footnotetext{
Abstract

Social work is usually seen as a profession with a localized focus but it is eclectic as it borrows from various disciplines for its theoretical framework, which makes it at times disjointed with no cohesion in the various dimensions of its practice. There have been several calls for a change of paradigm in Social Work. This paper takes a critical look at the profession and joins the myriad of calls for the expansion of the Social Work focus. In particular, this article introduces a peace paradigm, which would essentially integrate peace issues and peace perspectives into Social Work practice.
} 


\section{Introduction}

The United Nations Educational, Scientific and Cultural Organization's (UNESCO) (1995) culture of peace program is essentially linked to the universal values of personal peace, social justice, respect for fundamental human rights, cultural solidarity and tolerance, the sharing and free flow of information, demilitarization at macro and micro levels, economic security and development, political security and democracy, full participation and empowerment of women, environmental care and sustainable development. It calls for non-violent relations not only between states but also between individuals, between social groups, between a state and its citizens, and between humans and their environment.

In my engagement in areas related to Social Work, I have found that this profession has an extremely local focus. Social Work texts mostly address local issues while global concepts are themes usually addressed in specially designed courses labeled "Globalization". Unless Social Work students take these courses, they usually do not have exposure to global issues. The erroneous message is that there is a dichotomy between local issues and global issues and that each must be studied separately. The interconnectedness of both is often overlooked and ignored in Social Work programs.

Midgeley (2000) confirms that social work is a profession with a largely local orientation, whether working directly with individuals, families or at the community level. He adds that the national environment usually heavily influences Social Work but also states that most social workers function within the context of locally based delivery structures. He concludes that Social Work and social policy have historically been preoccupied with domestic activities and that it is only in recent times that efforts to enhance international awareness within the field have gained widespread support.

As we move on in the new millennium, massive changes are taking place around the world and they provide opportunities as well as challenges for Social Work both nationally and internationally. With the current trends in international affairs, this discipline can no longer function effectively without an understanding of the global environment. There is a growing acceptance today of the importance of understanding international events, engagement with them, learning from social structures, social welfare policies and cultures of other countries. Social Workers need to realize that work with individuals at the local level is influenced by problems of global scope. For example, poverty as a concept is usually viewed from local perspectives whereas this is a reality that affects not only local societies, but also quite intensely affects some global societies. Poverty within nations and among people and economic inequalities between them are realities that would affect the Social Work sphere. 
The discipline must put itself in a position to respond to realities of global interdependence. Social Work in Canada can no longer remain closed. What happens in other parts of the world affects what happens in Canada, just as what happens in Canada affects other parts of the world. This is a major concept in globalization as highlighted by Ife (2000). This researcher indicates that it has become imperative for Social Workers to not only adopt the feminist motto of Act Locally, Think Globally but that they should think and act at both local and global levels.

There have also been calls by Social Work activists like Torcyner (2000), Mullaly (1997), and Carniol (2000) to move Social Work from the passive role of service delivery to involvement in issues of global concern and critical engagement in discourses that are relevant to the field. Social work can contribute towards building a world order, which would overcome the sources of international tension, conflict, and armed violence that characterize the modern world. Glenn Drover (1998) states that what is left for the new breed of social workers is to struggle with others in creating a better world and avail themselves of the opportunity to participate in a global order in which all can celebrate each others' differences.

\section{Peace as a Global Issue and the Antithesis of Violence}

Peace is an issue of global concern. I believe that the various calls for Social Work's involvement in global issues could start with involvement in peace issues. Looking back on recent history, humanity has witnessed not only the destruction and suffering caused by wars and terrorist activities but also the major problems of poverty, inequalities, human rights violations, bloody interethnic and intercultural conflicts, and the devastating effects of environmental degradation. It cannot be denied that the world needs peace or more precisely attitudes, policies, and strategies whereby conflicts are settled nonviolently rather than through physical violence. Peace has thus been perceived and constructed as an antithesis to violence and has gone beyond the popular imagination of the mere absence of war.

There is a global presence of violence in all forms. Violence has been identified as (i) physical as in beatings, direct attacks, mutilations, shootings; (ii) systemic, socio-cultural, and psychological that manifests itself in discriminatory policies, practices, socioeconomic inequalities, injustice, inequities, massive poverty, and unemployment, underemployment which in recent times have been aggravated by policies of globalization and restructuring, sexism, racism, patriarchal domination, denials of economic, political, cultural and social rights; and (iii) ecological which disregards the sustainability of the environment. Peace is the absence of all forms of violence (Toh and Cawagas, 1987: 3).

As humanity continues its journey into the new millennium, the attainment of peace 
remains an enormous challenge facing all nations, communities and peoples worldwide. In response to the challenges of achieving peace, the United Nations appropriately declared year 2000 as the International Year of a Culture of Peace and this decade, 2000-2010, as the International Decade for a Culture of Peace and Nonviolence.

Fell (1988: 72) quoted a definition of peace given in the resolution of the 18th session of the General Conference of UNESCO, as follows:

\begin{abstract}
Peace cannot consist solely in this absence of armed conflict but it implies principally a process of progress, justice and mutual respect among the peoples designed to secure the building of an international society in which everyone can find his true place and enjoy his share of the world's intellectual and material resources. Peace is an active challenging option in the lives of all.
\end{abstract}

Peace is customarily defined in negative terms, like absence of war, absence of aggression, absence of dissent, absence of conflict. However, in post-war years, the peace concept has been broadened to include not only negative peace, which is absence of war, but also positive peace, which are ways of creating more just, harmonious and sustainable societies (Hicks, 1988; Kniep, 1986). An expanding movement of peace educators, researchers, and activists has shown that the idea of peace is multi-dimensional. Educators and activists of multiculturalism have also recognized that peace requires that in the contexts of cultural diversity, relationships between different ethnic and cultural groups need to reflect mutual respect, understanding, tolerance and harmony (Dei, 1994; Toh, 1990). They recognize that socio-cultural and psychological violence is vividly expressed in cultural domination, racism, sexism, religious discrimination and intolerance. Also worldwide, influential environmental movements have demonstrated that humanity needs to learn to live in harmony and balance with nature and its entire species because ecological violence continues to threaten the survival of humans and the earth itself (Suzuki, 1997; Fein, 1988; Pyke and Selby, 1988). A holistic concept of peace, has therefore gone beyond the problems of wars and the expressions of direct or physical violence

Nnoli (1988) deposes that peace is an important human value, a prerequisite for the attainment of other values. Reardon (1992) in her own contribution to the holistic concept of peace, described peace as a situation in which neither the overt violence nor the covert violence of unjust systems is used as an instrument for extending the interests of a particular nation or group. She added that it is a situation where human basic needs are met, where justice can be obtained, conflicts resolved through nonviolent processes, and human material resources are shared for the benefit of all people. Reardon (1992) therefore advocated a change in the concept of peace from being a product of a war system to what she labeled a paradigm of peace. She explained: 
If we are to experience an authentic fulsome peace, we must think peace. If we are to think peace we need a paradigm of peace to move us from a warring society to a parenting or caring society in which all adults parent the young and care for the vulnerable (392).

Schriver (1995) also says that shifting a paradigm is essential. On this premise, peace then is not passive. Peace is active. It is a 'doing' word. A peace paradigm therefore demands peace perspectives, peace thinking, peace actions and peace practices (Yesufu, 2000). It perceives violence as the root cause and mode of perpetuation of social injustice, poverty, hunger, racism, sexism, marginalization, exploitation, powerlessness, and cultural imperialism and promotes the absence of violence in all systems. A peace paradigm does not conform to nor accept the status quo but advocates that a society or world may seem superficially peaceful in the absence of actual physical violence, but in reality, there is a veiled violence constantly inflicted on the lives of human beings, through all forms of social injustice.

When it comes to the notion of justice, many people find the world, in some sense, unjust. The injustice could be the result of disparities in income, lack of political power, loss of human rights, racial or religious discrimination, and repressive state policies (Pearson, 1985). Roche (1985) points out that we live in an age of contradictions. For example, while there is famine in Africa, mountains of surplus food rot in North America. While the world boasts of magnificent technology, there is mass unemployment and underemployment. A peace paradigm therefore, has the responsibility of analyzing and understanding the root causes of injustices and empathizing with the plight and suffering of the poor and the marginalized people of society.

The concept of peace has been relatively unexplored in Social Work yet the relevance of peace to the field is quite evident. Fully aware of the global nature of peace, some social work activists have suggested the involvement of Social Work in peace building. Mehta (1997), for instance, wrote about the role of social work in peace building while Mullaly (1997) called for peace awareness for social workers. In particular, Mullaly (1997) highlights two perspectives of social work, the order perspective and the conflict perspective. The order perspective is synonymous with the functional or systems theory whereas the conflict perspective is consistent with the radical perspective. He identifies the peace movement as one of the radical movements involved in social reconstruction. $\mathrm{He}$ also sees oppression as the focus of structural social work. For him oppression is a social justice issue.

Thus, the involvement of social work in peace issues has been put forward, but unfortunately no one has given any specific indication of how this might be achieved at a practical level. This paper attempts to do just that; integrate a peace paradigm into Social 
Work practice.

\section{A Peace Paradigm in Social Work}

What is Social Work? I have read many definitions but the one that appeals to me is Pam Kwasnycia's (1998: 2) which says,

Social work is working with fellow human beings to make a difference in their lives and some times to make significant changes in the society they live and sometimes to do both.

I find the reference to changes in the society quite significant particularly as social workers tend to concentrate on their clients. As stated by Kirst-Ashman (1993), Social Work essentially has three major areas of focus: 1) to help those who cannot help themselves, and to provide for those who cannot provide for themselves; 2) to control the socially deviant; and 3) to seek the preservation and protection of the systems. In other words, Social Work looks at the inability and disability and says, there is a need here, let's go provide it but it does not go further to see why people cannot provide for themselves.

The National Association of Social Workers (NASW) Code of Ethics (Johnson 1986) states "The social worker should promote the general welfare of the society" (61). Barter (2000) claims that Social Work is losing ground in this area as regards its responsibilities on working towards social justice in the larger community. Ife (2000) believes that nonpolitical social work is an impossibility as Social Work cannot remain neutral. It is biased since it always seeks to maintain the status quo. He adds that the world is intrinsically, essentially evil and violent and that equilibrium for the world actually means power imbalance, lopsidedness, inequality, and one group having power over others, with the "violent" taking it by force. To work for peace is to upset this balance.

Hicks (1988) and Mullaly (1997) recommend changing paradigms within the discipline and argue that Social Work needs to go beyond its present boundary. Social work as a caring profession has all of the potential to move a society, in fact the world, from a warring position with its pervasive violence to a parenting and caring position. This it will do when it adopts a peace paradigm in its work and practice. A peace paradigm in social work would perceive and construct peace as an antithesis to violence.

At the moment there is a strong focus on family violence in the training programs of Social Work. Family violence primarily consists of spousal abuse, child abuse, parental abuse, elder abuse, sibling abuse, male/female partner abuse, and sexual abuse. Studies in violence include societal violence, power and violence, the cycle of violence, and men and women's involvement in violent acts. Social workers are taught to recognize violence in the home, in the family, in the individual and to report the acts. I believe the social worker 
needs to go beyond recognizing and reporting abuse and violence. The social worker needs to know and recognize peace as the option for violence. The emphasis here is on raising awareness not just about physical violence but all the ramifications of violence: personal, structural, systemic, institutional, socio-cultural, psychological, organizational, and ecological, and acknowledging that unpeaceful conditions lead to conflicts on local, national, and international planes.

Violence has continued to be utilized to marginalize and oppress people and minorities all over the world. The continuous calls for the construction of peaceful societies are therefore timely. Social Workers need to be involved in building these peaceful structures and dismantling violent structures, which have, and continue to ravage many societies around the world. A peace paradigm needs to be integrated into Social Work programs in order to raise awareness of such social problems.

\section{A Peace Paradigm in Development Issues and Social Work}

If Social Work is to change the environment in which it operates, it also needs a different focus on development issues. Development implies change for the betterment of the individual, the society in which the individual exists, and the world at large. Underdevelopment is about the effects of poverty, malnutrition, hunger, disease, human rights denials and all such indignities on a person (Young, 1993). Development is both internal and external and is also about justice, which in essense is giving each person his/her due. It is also about peace. McGinnis (1984) stressed that where there is justice, there will be peace and where there is peace there will be development. Pope John Paul affirmed this at the celebration of the 1972 Day of Peace (Ward, 1973: 11) when he admonished, "If you want peace, work for justice."

A peace paradigm in development issues identifies with the struggles of all oppressed peoples and identifies the root causes of all forms of violence. Social Work identifies personal violence, but does not address its root causes, neither does it focus on all forms of oppression.

I believe that Social Work needs to identify the root causes of violence in all systems and provide a means of addressing them in practice. It needs to understand that poverty, deviance, and dysfunction in the lives of clients may not always be internally generated, but may be a reaction to the social environment; that root causes of poverty could be extraneous forces working against the client. These include injustice, inequalities, inequity, domination, oppressive and discriminatory laws, hegemony, racism, consumerism, ethnic and religious differences, ignorance, greed, individualism, unemployment, elitism, economic insecurity and political disempowerment. Social workers need to understand these root causes for effective delivery in order that they may 
help their clients to understand their own position in the broader society, and the effects of society on their lives.

Bryant and Soest (1995) agree that Social Work has been taciturn, in fact, complacent about societal and structural violence because of the heavy focus that has been placed on family violence. The development dimension in Social Work practice would highlight the key concepts of structural and societal violence. This is a manifestation of inequality and the decline of structures in the areas of income, health, economic, political, educational and other aspects of social well-being at the national and international level.

The Social Work discipline needs to work for peace and needs to promote peace on the job. A peace paradigm in Social Work practice would preach peace though strength. It would advocate empowerment, not in terms of power which is usually endorsed by some individuals and oppressive institutions, but rather empowerment as a process through which people will reduce their powerlessness and alienation and gain greater control over all aspects of their lives and their social environment (Mullaly, 1997).

Social Work has the responsibility of promoting the understanding of key global issues that have an effect on the quality of life of people. It should also have empathy with the plight and suffering of the poor and marginalized groups of the world. A peace paradigm in Social Work would encourage involvement in international development issues particularly with respect to the growing disparities between North and South countries in the global system. Despite some global economic growth, the poor majority of the world have remained marginalized. Originally the emphasis of international development issues was on the Third World which has been deemed as economically disadvantaged and poor. But the notion of Third World has been expanded to encompass all those areas and groups who are, in some way, marginalized by the workings of the economic and political systems. These include women, the aged, the homeless, the unemployed, ethnic minorities, indigenous people, and even the poor remote and un-influential parts of wealthy countries (Pyke and Selby, 1988). The truth is that the Third World is not just a geographic location; the Third World exists even in the First World.

Sherlock and Hubert (1989) grimly state that it is a tragic fact that today when human civilization has progressed so tremendously in the scientific and technological spheres, there are still billions of people who remain hungry throughout their life spans. While space shuttles are regularly launched into the heavens, while deadlier and more accurate missiles are invented by millions of scientists and engineers all over the world, while a minority of privileged human beings can consume excessively and trivially, a large portion of humanity remains desperately poor and unable to meet their basic needs. 
The poor in many countries of the world, Canada included, have remained marginalised by the workings of the global economic and political systems. There is no doubt that the world has enough natural resources and can produce enough goods to feed, clothe, house and serve the basic necessities of the entire global family. The phenomenon of hunger and poverty is primarily a problem of mal-distribution of these resources. Assessing the world situation, Mahatma Gandhi (1992) indicated that there was enough for the need of this world but not enough for its greed.

A peace paradigm in Social Work and development issues would cultivate a critical understanding of and be an alternative voice for development at both the local and global levels. It would identify with the struggles of all oppressed peoples all over the world, with a focus on their suffering, chronic lack of basic needs, and unjust and exploitative global economic systems. As analysts such as Dei (1994), Amin (1976), and Toh (1987) have emphasized, the dominant modernization paradigm of development has benefited disproportionately the elites and powerful agencies of both North and South societies and transnational corporations.

\section{A Peace Paradigm in Social Work Advocacy for Social Change}

A peace paradigm in Social Work advocacy for social change would include increased awareness and sensitivity. The Canadian Association of Social Workers (CASW) Code of Ethics and Guidelines for Ethical Practice (1999) states, "Social workers shall advocate for change in the best interest of client and for the overall benefit of society, the environment and the global community" (28). However, as indicated by Mullaly (1997), Social Work is a profession founded on conservatism while Carniol (2000) complained about the passive nature of social workers. He stated that social workers do not traditionally speak against injustices and they do not critically challenge issues that affect them. They are not trained to. In most cases, they are trained to conform to policies and guidelines.

Kemp (1995) asserted that Social Workers were usually uncomfortable with community intervention for social change, but more comfortable with personal intervention, because that is what they are trained to do. Wells (2000) questioned whether Social Work was training professionals to become handmaidens to the bourgeois carrying out draconian practice methods that ensure the stability of the status quo rather than training students to become agents of social change.

A peace paradigm in Social Work advocacy for social change demands knowledge about the decline of social development in all societies. However mere knowledge is not enough. It demands that political and economic issues be focused on and that there be a leading voice against all forms of oppression and injustice. 
Social Work practice normally focuses on mediation, consensus, collaboration, and teamspirit, and yet there are instances when such approaches do not meet the needs of the individual and the community. A peace paradigm in Social Work advocacy for social change would focus on a wider scope of mediation and would mean not only speaking against all forms of violence, but also organizing against violence, and organizing for peace. No longer would Social Work be defined as just the helping profession, but a profession with an alternative voice. A peace paradigm in Social Work advocacy for change would mean involvement in social action; taking non-violent actions to overthrow violent structures at all levels.

\section{A Peace Paradigm and Human Rights Issues}

The sanctity and importance of various human rights and freedoms can be found in the Universal Declaration of Human Rights, successive international legal instruments, and the National Constitution of several countries. But in practice as often widely reported such human rights are often neglected, abused, or violated. Human rights encompass those rights that make a person human, enabling one to develop fully and allowing people to live in community and realize the richness of their talents, culture, resources and non-material gifts (Selby, 1987; Romany, 1994). Human rights guarantee the freedom of individuals to participate in the activities necessary to facilitate peace and harmony in society. Human rights information is the foundation for social justice, equality, and empowerment and creates conditions under which domination and oppression can be overcome and transformed through deliberate and collective action in the struggle to secure the rights of the individual and the collective (McLaren, 1989). However, these rights are difficult to sustain unless all people enjoy basic economic, social and cultural needs. As Lomasky (1984) indicates, the denial of rights constitutes a form of structural violence, in interpersonal relationships, client/worker relationships, and agency/worker relationships. Structural violence denies many people their fundamental rights, to adequate food, shelter, education, and other basic needs. It also denies them freedom from exploitation and repression.

A peace paradigm in human rights acknowledges and accords respect for basic human rights. It addresses the violations of social, cultural and economic rights of all people. Carniol (2000) observed that the Social Worker is confronted each day with power dynamics, in the form of client versus worker, worker versus agency, client versus agency, agency versus establishment. In each of these situations, the worker, the client and the agency are technically denied their rights when policies and practices are not in their best interest. He further opined that agencies are also denied their rights when they succumb to draconian laws by the establishment and cannot raise a voice for fear of losing funding. 
A peace paradigm in Social Work practice would focus not only on enhancing awareness of human rights, but also on promoting the dignity of all people. It would teach that all people are equal and equally human and it would focus on the abolition of power relationships, accord respect, and teach that all children are precious (Eide, 1983).

The UNICEF's Convention of the Rights of the Child (1995) recognizes that children deserve to enjoy the fulfillment of their human rights. It also states that respect for human rights begins with the way society treats its children. The Convention recognizes that people owe children the best they have to give and that young children be taught and groomed in such a way that they do not imbibe the prejudices of the society (Brock-Utne, 1985). But children being the most vulnerable of the human race, often become easy victims of exploitation. All over the world, many children continue to live in deprivation. Starving children are not only found in Africa where I come from, but inequality and discrimination with the resultant poverty are issues that children even in Canada, a First World country, have to contend with. (UNICEF 2000) It is suggested that a peace paradigm in Social Work and human rights issues will go beyond the local issues relating to child welfare and family intervention and once again focus on, and recognize, global problems.

In another vein, Diokno (1983) revealed the connection between human rights and national identity. Recognition of human rights is to recognize the limits of government authority. All people have a right to self-determination, which enables them to work out their own development priorities, goals and directions. This is particularly relevant with Canada's First Nations Peoples' right to self-rule. Democracy does not only encompasses rules, institutions, and systems, which uphold civil and political freedoms, it also upholds economic, social, and cultural relationships, which are equally democratic, just and equitable (Knop, 1994).

Human rights information embedded in Social Work practice would enable practitioners to become more prepared to pre-empt any tendencies towards political oppression and ensure that authoritarianism in government is clipped. Social Workers need political literacy to critically analyze and contribute to national policy making, because they shape practice. Social policy is a course of action chosen by public authorities to address a given problem or interrelated set of problems. Barker (1995) defines it as the activities and principles of a society that guide the way it intervenes in a regulated relationship between individuals, groups, communities and social institutions. Policies cannot therefore be fully left to politicians, bureaucrats and the so-called experts who are at times removed from reality. These are theorists without praxis. Social policy-making is complex. It requires special skills, interpersonal, interactional, intellectual and analytical, which every Social Worker should be encouraged to develop. All of these are human rights issues, which the 
Social Worker must be involved in.

\section{A Peace Paradigm in Intercultural Solidarity}

A Peace paradigm promotes intercultural solidarity. This is the understanding of tolerance, acceptance and respect for cultural identity. It is reversing the effect of imperialism and colonial policies and avoiding the tendency to impose a universal culture. It is accepting of a world of pluralism and diversity, a process, which increases the level of respect, sensitivity and knowledge about and among varied cultural and racial groups. It incorporates the beauty and riches of all groups into the whole system and it increases an appreciation of commonalty and diversity among people as an enriching condition (UNESCO, 1995). Pyke and Selby (1988) state that mono-cultural information stunts the growth of critical thinking.

Multiculturalism recognizes the multiple cultures but interculturalism emphasizes the interrelatedness of all the cultures. Intercultural solidarity not only sees cultural differences but offers the opportunity to experience commonality in these differences. It increases awareness of different social systems, organizations and traditions that constitute the world and it emphasizes the universal values, that unite people of different cultures, noting the fact that people are living in an integral yet interrelated world, and that all belong to the same species, live on the same planet with sacred rights to exist, develop and determine their own lives. (UNESCO, 1995).

Canada is a culturally diverse society. Most Social Workers lack substantial experience with different cultures. They tend to have little knowledge of the major difficulties experienced by people of color, the historical treatment of Natives, of Blacks and other minorities like Chinese and Japanese, the individual and institutional racism that racial minorities experience on a daily basis. They are not aware that minorities have been victims of discrimination at the hands of almost every social institution; schools, health care, justice, and government. This is because these components are not adequately represented in the Program. Social Work cannot continue to combine people of all races together, pretend that culture has no role in determining behavior, and assume that all clients think alike. Intercultural sensitivity is minimal in Social Work practice. As indicated by Randall-David (1989), there is need for increased understanding of the experiences of people of color, their family patterns, their modes of communication and meaning.

A peace paradigm in intercultural solidarity in Social Work practice would focus on helping multi-ethnic societies in building mutual respect (Dei, 1994). It would promote solidarity for each other's identities and acknowledge the fact that issues and problems in Social Work are transnational in scope and therefore can only be solved through 
intercultural awareness, intercultural action and cooperation. This will not only reduce labeling and stereotyping but it will make Social Work accountable and responsible in its practice.

\section{A Peace Paradigm and the Feminization of Culture}

a) Issues Relating to War

A peace paradigm promotes the feminization of culture. This concept refers to replacing the warring militarized system, which has characterized the male dominated social hierarchy and authority with a more feminine nurturing system. Women have contributed significant efforts in movements for peace in diverse cultural, social and geographical contexts and they have become highly visible within peace building groups and initiatives (Sylvester, 1992). For example, polls show that women oppose budget increases in military expenditures and deployment of new weapons more frequently than men (BrockUtne, 1985). It is therefore common to think of women as being pro-peace. Women in general have sometimes been characterized as natural pacifists with a proverbial interest in peace (Aronof, 1986). In essence, women's struggle for peace is connected to the concern for human life, for children, for themselves, and for other women. Women always strive to reach other women in the opposite camps and they usually employ a varied set of nonviolent techniques, acts, strategies to resolve issues (Brock-Utne, 1985).

Are women therefore more peace-loving than men? Women are considered to be natural peace lovers. Saraicino (1988), for instance, concluded that human aggression is a problem for men, not women, as it is men who wage wars, engage in bitter competition, fight each other individually, and maintain vendettas lasting for years or even decades. Schreiner (1991) said that men have made boomerangs, bows, swords or guns with which to destroy one another. She adds that there is no battlefield on earth, which it has not cost the women more in actual bloodshed than it has cost the men who lie there. According to Vellacott (1988), women's peace efforts are often dismissed as simply part of the general softness of women's nature or as part of their motherhood role. Brock-Utne (1985) believes that women have never institutionalized violence as girls are taught to be more submissive, less demanding and more nurturing than males. Women fulfill their assigned roles in war as well as in peace sacrificing their sons, husbands and lovers without complaining but mourning their loss (Vellacott, 1988). Sylvester (1992) however does not think it is an advantage for women to be so docile. She believes that they should embrace classical Marxism, which she says has a warrior philosophy that helps to fight the patriarchy that has bolstered male supremacy.

Mahatma Gandhi (1992) viewed women as the incarnation of ahimsa and added that due to different socialization processes, women have tended to grow up more peaceful than men and more capable of solving conflicts in a nonviolent manner. He felt that peace often 
started in the minds of women. Margaret Atwood once commented that as far as she has heard, war and rape were two activities not extensively engaged in by women (Vellacott, 1985) while Brock-Utne (1985) argued that while men perpetrate most of the world's violence, most of its nonviolent nurturing is done by women. Many women's human rights organizations of the late nineteenth and twentieth centuries held the same view as they saw world peace as part of their vision for a new society (Ruether, 1987). In other words, women usually assume roles of peacemakers in families, in communities and in societies. Women are seen as saviors of the world (Brock-Utne, 1985).

Historically women have made efforts in movements for peace. Peace Pilgrim the indomitable American Woman (1951-1981) covered 25,000 miles on foot for peace and vowed to continue to walk for peace until human beings had learned the way of peace (Pilgrim, 1994). Betha von Suttner (1843-1914), the German actual initiator of the Nobel Peace Prize (without whom there would be no Nobel peace Prize) worked relentlessly to promote peace. She was the one who having known and worked closely with Alfred Nobel urged him to set aside a prize for anyone who worked for peace. Interestingly enough, Alfred Nobel had invented dynamite, a weapon of destruction and made a fortune from this invention, but still regarded himself as a pacifist. Betha was never mentioned, until she herself received a prize (Vellacott, 1988)

\section{b) Issues Relating to the Workplace}

Rojek, Peacock and Collins (1988: 77) stated that

Social Work should be a cause celebre for women, a profession created for women. Yet in reality women workers operate as the foot soldiers in an army governed by male generals and deal regularly with women clients who are the victims of male oppression."

Women are the largest consumers of social programs and constitute the largest pool of Social Workers, yet the theory and practice still does not reflect appreciation of women's contribution to the profession. In fact, there are more men than women in senior social work positions. (Rojek, Peacock, and Collins, 1988)

A feminization of culture in a peace paradigm would address the role of exploitation of women in the Social Work sphere and would assess the need for greater gender sensitivity. Throughout the world, women are vital co-producers of national wealth from the land, in factories, and at home, yet they remain marginalized, exerting less political influence than men, receiving unequal social economic services and rewards such as wages, nutrition, health and education (Sotela, 1994).

A peace paradigm relating to the feminization of culture in social work would imply that 
non-sexist and gender-equity perspectives in Social Work should be introduced. Social Workers, both male and female, would be made aware of injustices experienced by women at work and at home due to male domination and patriarchal traditions. It would focus on the socialization process in institutions and ensure that women's worth is not depreciated. Women too would not denounce their rights to fully participate in social economic and political life. A feminization of culture in Social Work would dictate gender sensitivity, showing that working with women is different from working with men. Feminist issues would become an essential and basic part of training for a Social Worker and it is suggested that such training not be an option, but rather a required course.

\section{A Peace Paradigm and Environmental Issues}

A peace paradigm engenders sensitivity to environmental issues. It addresses the dimensions of the environment crisis around the world and the effects of environmental decline on the quality of life. Worldwide, influential environmental movements have demonstrated that humanity needs to learn to live in harmony and balance with nature and its entire species because ecological violence continues to threaten the survival of humans and the earth itself (Suzuki, 1997; Fein, 1988; Pyke and Selby, 1988). Sustainability and sustainable development are essential building blocks of a peace paradigm. Responsible scientists and concerned people all over the world are increasingly alarmed over the rapid deterioration of the natural environment. The range of ecological problems is wide and is continually expanding. These problems include global warming through the greenhouse effect, the depletion of the ozone layer, the destruction of rainforests in all continents, accompanied by secondary consequences like landslides, silting and losses of crops, pollution of air, land, and water lakes due to toxic industrial wastes (Barnaby, 1988, Kaufman and Frantz, 1993). Of all the species that make up life on the planet, human beings are the most critical actors in the ecological system. The interdependence and symbiotic relationship of living and nonliving things and the special role that human beings play in the ecological system cannot be undermined. All countries and peoples have a share in ecological destruction.

Environmental sensitivity in social work would emphasize the interdependent nature of all components of the biosphere, including human communities and thus directly link the future of the planet's life support systems to human behavior and development decisions (Kaufman and Franz, 1993; Suzuki 1997). It would foster and reinforce a new ethic, which would assert new attitudes and behaviors that are required for human societies to live in harmony with the natural world on which they are dependent for survival and well being (Naess, 1990). It would dictate that we live peacefully with the earth and practice environmental care; otherwise the survival of human species will be in great jeopardy. A peace paradigm in environmental issues would teach that people should respect and acknowledge their unique place on the planet and understand that individual actions 
contribute to the sustaining or destruction of the whole ecological system (Mische, 1989). It would also help Social Workers to visualize a peaceful world as living harmoniously with all the elements of our planet earth, a place where everyone can share responsibility and benefit equitably of the lands, waters, air and other forms of common heritage (Mische, 1989).

Social Work has borrowed the term ecology for one of its theoretical perspectives. It defines the ecological relationship as that external and social environment which exists in family, politics, groups, religion, goods, services, education and in all sorts of various systems (Kirst-Ashman, 1993). However it should be noted that Social Work has little or no focus on the biosphere and other atmospheric issues. Engagement with these is visibly absent in the Social Work curriculum. It is proposed that a peace paradigm in environmental issues in Social Work focus on the dynamic relations and transactions with various forms of ecosystems, explore the question of humanity's relationship with the biosphere and encourage the critical ability to consider in what ways people need to modify their behaviors, and values so as to bring greater harmony and peacefulness to that relationship (Kaufman and Franz, 1993).

\section{A Peace Paradigm in Relation to Personal and Societal Peace}

A peace paradigm is a search for personal and societal peace. Hence peace depends upon the creation of peace-loving individuals who will have both the cognitive and affective drives to work for a peaceful world. Personal peace is the satisfaction of basic human necessities including not only material needs but also political, social, judicial, cultural, economic, psychological and spiritual needs. Societal peace is a peaceful, secure existence of people within their communities.

A peace paradigm in societal peace in Social Work practice would study violence in the media, violence in schools, and even in sports fields. The rampant shootings in schools in Canada, in the United States, and other places in the world that we read and hear about in the media illustrate the tragic consequences of micro levels of societal violence. Equally the incessant abduction and killings of children and youth that we also hear and read about in the media illustrate the level of depravity of human society. A case in point is the JonBenet Ramsey case in Denver Colorado. A peace paradigm in Social Work and societal peace would engage in the discourse on demilitarization and reckless possession of guns. It would propose that investments on arms should be converted to meeting basic human needs like food, housing, health care, jobs and education. Family support in social work would include discouraging war toys for children, violent television and movies, and all those things that heighten violence in the society.

A peace paradigm would also seek to develop inner peace and equilibrium to cope with 
the pressures of life. Among faiths and religions, there has been a quest to attain peace of mind, heart and spirit through spirituality. Meditation and visualization is a practice in Social Work with clients. This applies to the sense of compassion; a concept the Social Worker is quite familiar with. A peace paradigm in personal peace in Social Work would focus not only on the peace-mindedness of the client but also on that of the social worker. As indicated by Cox (1986), the building of a peaceful world necessarily requires that we have to work on ourselves and cultivate a strong sense of personal peace.

One problematic dimension of Social Work that is increasingly receiving greater attention is burnout and self-care. As Selby (1993) noted, peace is not only about the journey outward but also the journey inwards towards personal and spiritual growth. There is a growing concern about personal alienation and peacelessness in the midst of excessive materialism and consumerism. The extreme pressure of modern living and the rat race have brought anxiety, depression and mental stress to many, including social workers. These result in neurosis and various addictions, which social workers not only have to work with, but also have to contend with themselves. (Fewell, King, and Weinstein, 1996)

Carniol (2000) reports that many social workers face frustrations, from low pay, lack of fulfillment on the job, heavy case loads, overwork, and long hours of work with minimum pay. Butler (1996) deposed that the body reacts to extreme stress by releasing a cascade of cortisol adrenaline and other hormones, which damage brain cells and impair memory and set in motion a long lasting and worsening deregulation of the body.

Personal peace must go hand in hand with outer or societal peace. Sherlock and Hubert (1989) states that it is clear that no one can truly have personal peace until the whole world finds justice. An individual's personal peace is vital to the attainment of societal peace because the individual values, attitudes, and layers of consciousness, can directly or indirectly help to sustain the resistance to societal violence. Social Work should work towards the attainment of a peaceful world, which involves the well being of all peoples and maintenance of relationships and systems that are just, equitable, and nurturing.

\section{A Peace Paradigm in Social Work Education}

Barnaby (1988) and other peace researchers and activists have argued that violence is not inherent in human nature but rather it is a social construct. Rohr (1992) also says violence is something we learn. In other words, just as violence is learned, peace can be learned (Reardon, 1992). Peace knowledge, peace concepts, peace practices, and peace attitudes all amounting to a peace paradigm will come about through peace education. There is a clear and strong consensus among practitioners and scholars that peace can be built effectively only through appropriate educational processes and strategies. Reardon (1985) also states that building peace requires the vital dimension of education at all levels and in 
all forms, formal, informal and non-formal.

If a peace paradigm is to be assured in Social Work it must be reflected in Social Work education. Social Work theory and practice is based on diversity and is multidimensional. It is eclectic as it borrows from all disciplines and has a wide theoretical base. At times, the discipline is viewed as fragmented. Turner (1999), for example, identified thirty different methods and theories employed in the discipline of Social Work. I argue that Social Work needs cohesion by implementing a peace paradigm that is multidimensional yet holistic. Once integrated into Social Work education, unity in diversity will be achieved.

A peace paradigm in Social Work education would be transformational. It would promote a new way of thinking (UNESCO 1995). It is crucial that Social Workers are not left with a fragmented understanding of issues. Rather a peace paradigm, which is holistic, will address the problems of peacelessness and emphasize the interrelatedness of all the issues. It will also seek to develop critical thinking (Sokolova, 1995). A peace paradigm in Social Work education will ensure the understanding that others may be different, yet we need to learn to respect and value those differences rather than despise, fear or denigrate them. It will also ensure that our actions do not harm others. With peaceful practices, a society will begin a process of transformation. Apathy and hopelessness will be replaced by selfconfidence and hope. The marginalized and the poor themselves will begin to actively struggle in nonviolent ways for changes, which will bring humane development, social justice, equity, and radical redistribution of wealth. In their engagement with the elites, Social Workers will promote transformatory measures, which will involve the awakening of their conscience to the consequences of injustice. A peace paradigm in its transformational role would seek non-violent alternatives to direct violence, social justice in place of injustice, ecological balance in place of environmental damage, and meaningful participation in all spheres of life in place of alienation. A peace paradigm in Social Work education would not just be learned, it would be lived.

A peace paradigm in Social Work education would promote conscientization. This can be likened to Freire's (1973) model of critical consciousness raising for action, for practical achievable change, and for practicing values. Paulo Freire had used the principles of conscientization in his work with marginalized peoples in the South. He says education cannot rely on 'banking' strategies but must encourage learners to contribute their own insights, experiences and realities in developing a critical understanding. He therefore encourages dialogue, which is central to a peaceful pedagogy. Unlike the concept of communication in Social Work, which focuses on how information is conveyed and received, conscientization facilitates a process of action (Freire, 1973) which usually leads to social empowerment. Conscientization enables people to work together with confidence 
and self-esteem, inspired by the vision, hope, and imagination. It involves cooperation and non-violent social change aimed at creating more equitable and just structures in a society (Freire, 1973). A peace paradigm in Social Work education would not only promote the physical and mental well being of all persons but would work to maintain their human dignity and self determination. Conscientization would lead to action.

A peace paradigm in Social Work education would promote, peace-oriented consciousness, and move Social Workers to undertake action on the basis of their selfrealized responsibility. Such action will include (i) personal action, which is what individuals can do to make their personal and interpersonal environment more peaceful, and (ii) social action, what individuals can do in solidarity with each other as groups, movements, institutions, citizens, communities, to achieve peace. (Yesufu, 2000). Conflicts are unavoidable happenings in the realities of human relationships whether between and among members of a family, communities, organizations, agencies, friends, colleagues, employees, employers, citizens, leaders and even among nations. A peace paradigm in Social Work education will view such conflicts as having a constructive side which would encourage people to resolve conflict through active non-violence.

A peace paradigm would also be futuristic. Slaughter (1988) believed that education must look into the future, and added that a futuristic education must deal with fears about the future. In 1988, Betty Pichard looked at the future and saw the expansion of social work to include involvement in religion, economics and politics, which have both local and global dimensions. It is proposed that a peace paradigm in Social Work education will develop in practitioners a deep sense of optimism for the future. Life is a progression. A good grasp of the present by Social Workers will allay fears and lead to what Pichard (1988) calls probable and preferable futures. This, in essence, means a more just and less violent world.

Reardon (1992) says that a peace paradigm involves concepts, languages, images and metaphors of peace to help organize a peaceful society in which we can conduct human affairs in a more humane manner. She also says the primary function of a peace paradigm is to help people in doing, acting and becoming (Reardon, 1985). The vision of this paper is that through the integration of a peace paradigm into Social Work education, there will arise an army of Social Workers with peace perspectives, who will transform Social Work conduct and practices. Social Work as a helping profession will become action oriented, involved in challenging a structurally violent world, while operating and promoting a P.E.A.C.E. paradigm which stands for Peaceful, Empathetic Approach to Conscientization and Empowerment (Yesufu, 2000)

Finally, I will borrow from what Brigit-Utne (1985) said on women's role in transforming 
the society. I will substitute the word(s) women with social workers. I therefore state that if social workers who have the essential nurturing ingredient start working with peace policies, continue to care for others, become more assertive, feel more compassion, believe in themselves, develop the passion and endurance to struggle for a more humane and peaceful world, they have a chance to transform the society and change the world. 


\section{REFERENCES}

Amin, S. 1976. Unequal Development. New York: Monthly Review Press.

Aronof, P. 1986. “A Feminist Approach To Militarism and Peace." In Roots of Peace.

E. Shragge, R. Babin, and J. Villiancourt (eds.). Toronto: Between the Lines, pp. pp. 95-103.

Barker, R.L. 1995. The Social Work Dictionary. Washington, D.C.: NASW Press.

Barnaby, F. 1988. The Gaia Peace Atlas. Sydney: Pan. Publishers.

Barter, K. 2000. "Reclaiming the Community: Shaping the Social Work Agenda." Canadian Social Work, Vol. 2, Issue 2, pp. 6-18.

Bretherton, D. 1991. “A Rainbow Journal.” In Journeys in Peace Education. SweeHin Toh (ed.). Manilla: Earth, pp. 15-32.

Brock-Utne, B. 1985. "The Relationship of Feminism to Peace and Peace Education.” In Peace Education and the Task for Peace Education. T. Carson and H. Gideonse (eds.). Canada: W.C.C.I., pp. 57-63.

Bryant, S. and D. Soest. 1995. "Violence Reconceptualized for Social Work: The Urban Dilemma.” Social Work, Vol. 40, No. 4, pp. 549-557.

Butler, K. 1996. "Researching PSTD: The Biology of Fear.” Family Therapy Networker, Volume 20, Issue 4, pp 39-45.

Canadian Association of Social Workers (CASW) Code of Ethics and Guidelines for Ethical Practice (1999). Ottawa CASW.

Canadian Association of Social Workers (CASW) Code of Ethics and Guidelines for Ethical Practice (1986). Ottawa: CASW.

Carniol, B. 2000. Case Critical: The Dilemma of Social Work in Canada. Toronto: Between the Lines.

Cox, G. 1986. The Ways of Peace. Cambridge: James Clarke \& Co.

Dei, G. 1994. Anti-Racist Education, Working Across Differences. Toronto: Orbit. 
Diokno, J. 1983. "Human Rights: Teaching and Research in the Context of Development, The East/West, North/South Conflicts." In Frontiers of Human Rights Education. A. Eide and M. Thee (eds.). Oxford: Basil Blackwell Publisher Limited, pp. 35-42.

Drover, G. 1998. "Social Work: Our Roots Our Future.” The Social Worker, Vol. 66, No. 3, pp. 79-91.

Eide, A. 1983. "Dynamics of Human Rights and The Role of Education.” Bulletin of Peace Proposals, Vol. 14, No. 1, pp. 105-114.

Fein, J. 1988. "Environment Education: A Perspective for Teacher Education." Journal of the World Council for Curriculum and Instructions, Vol. IV, No. 1, pp. 30-39.

Fell, G. 1988. "Peace." In Education for Peace. Issues, Principles and Practice in the Classroom. D. Hicks (ed.). London: Routledge, pp. 71-86.

Fewell, C.H., King, B. \& D. L. Weinstein. 1996. “Alcohol and Other Drug Abuse Among Social Work Colleagues and Their Families.” Social Work, Journal of the National Association of Social Workers, Vol. 38, No. 5, pp. 565-570.

Freire, P. 1973. Education for Critical Consciousness. New York: Seabury.

Gandhi, M. (1992). “Ahimsa, or The Way of Nonviolence.” In A Peace Reader. J. Fahey and R. Armstrong (eds.). New Jersey: Paulist Press, pp. 171-175.

Hicks, D. 1988. “Changing Paradigms.” In Education for Peace: Issues, Principles and Practice in the Classroom. D. Hicks (ed.). London: Routledge, pp. 269-274.

Ife, J. 2000. "Localized Needs and Global Economy: Bridging the Gap with Social Work Practice.” Social Work and Globalization, Special Issue.Vol. 2, No. 1, pp.

Johnson, L.C. 1986. Social Work Practice A Generalistic Approach, 2nd Edition. Massachusettes: Allyn and Bacon.

Kaufman, D. \& C. Franz. 1993. Biosphere 2000: Protecting our Global Environment. New York: Harper Collins College Publishers.

Kemp S. 1995. "Practice with Communities." In The Foundations of Social Work Practice. C. Meyer and M. Mattani (eds.). Washington: National Association of Social Workers (NASW) Press, pp. 176-203. 
Kirst-Ashman, K. 1993. Understanding Generalist Practice. Chicago: Nelson Hall Inc.

Kniep, W. 1986. "Defining Global Education by its Contents." Social Education Journal, Vol. 3, pp. 437-446.

Knop, K. 1994. "Why Rethinking the Sovereign State is important for Women's International Human Rights Law." In Human Rights of Women: National and International Perspectives. R.Cook (ed.). Pennsylvania: University of Pennsylvania Press, pp. 153-164.

Kwasnycia, P. 1998. "Social Work: Is this the Job for You?" Business and Employment Trends, April-May, pp. 2-5.

Lomasky, L. 1984. "Personal Projects as the Foundation for Basic Rights.” In Human Rights. E. Paul and F. Miller (eds.). Oxford: Basil Blackwell Publishers Limited, pp. 35-54.

Lynch, E. 1996. Developing Cross-cultural Competence. New York: Praeger.

McGinnis, J. 1984. Educating for Peace and Justice. Missouri: Institute for Peace and Justice.

McLaren, P. 1989. Life in Schools: An Introduction to Critical Pedagogy in the Foundations of Education. New York: Longman.

Mehta,V. 1997. “Social Work in Peace Building.” In Issues In International Social Work: Global Challenges for a New Century. H. Merl and J. Midgley (eds). Washington, DC: NASW Press, pp. 93-109.

Midgeley, J. 2000. "Globalization, Capitalism and Social Welfare A Social Development Perspective.” Social Work and Globalization, Special Issue, Vol. 2, Issue 1, pp. 13-28.

Mische, P. 1989. "Ecological Security in an Interdependent World." Breakthrough, Summer/Fall Edition, pp. 7-18.

Mullaly B. 1997. Structural Social Work: Ideology, Theory, and Practice. Toronto: Oxford University Press.

Naess, A. 1990. "Sustainable Development and Deep Ecology." In Ethics of Environment and Development. J.R. Engel and J.G. Engel (eds.). London: Belhaven Press, pp. 88-96. 
Nnoli, O. 1988. "Realizing Peace, Development and Regional Security for Africa: A Plan for Action. In African Perspectives on Peace and Development. E. Hansen (ed.). London: ZED Books Ltd., pp. 215-232.

Pearson, G. 1985. Peace and Education. In Implementing Peace Education. W. Brower and T. Carson (eds.). Edmonton: International Institute for Peace Education, pp. 93-102.

Pichard, B. 1988. Introduction to Social Work. A Primer. Chicago: The Dorsey Press

Pilgrim, P. 1994. Peace Pilgrim: Her Life and Work in Her Own Words. Santa Fe: Ocean Tree Books.

Pyke, G. and D. Selby. 1988. Global Teacher: Global Learner. London: Hodder and Stroughton.

Randall-David, E. 1989. Strategies for Working with Culturally Diverse Communities and Clients. Toronto: Association For the Care Of Children's Health

Reardon, B. 1992. “Towards A Paradigm of Peace.” In A Peace Reader: Essential Readings on War, Justice. Nonviolence And World Order. J. Fahey and R. Armstrong (eds.). New Jersey: Paulist Press, pp. 391-403.

Reardon, B. 1985. "Feminist Concepts of Peace and Security. In A Reader in Peace Studies. P. Smoker, R. Davies and B. Munske (eds.). Toronto: Pergamon Press, pp. 136-143.

Roche, D. 1985. “The Problems and Prospects for World Peace.” In Implementing Peace Education. W. Brouwer and T. Carson (eds.). Edmonton: International Institute for Peace Education, pp. 16-42.

Rohr, S. 1992. "Breaking the Chain of Violence." Canadian Lutheran, Vol. 7, No. 5 , pp. 16-18.

Rojek, C., Peacock, G., and S. Collins. 1988. "Women Social Work and Feminism" In Social Work and Received Ideas. C. Rojek, G. Peacock and S. Collins (eds.). Surry, Routledge, pp. 77-116.

Romany, C. 1994. "State Responsibility Goes Private: A Feminist Critique of the Public/Private Distinction in International Human Rights." In Human Rights of Women: National And International Perspectives. R. Cook. (ed.). Pennsylvania: University Of Pennsylvania Press, pp. 85-115. 
Ruether, R. 1987. Feminism and Peace in Women's Consciousness: Women's Conscience. New York: First Harper and Row.

Saraicino, M. 1988. "Woman, The Unwilling Victim of War." In Peace Movements and Political Culture. C. Chatfield and C. Dungen (eds.). Knoxville: University of Tennessee Press, pp. 95-105.

Schreiner, B. 1991. "Men and Violence." In Understanding and Preventing ViolenceNational Research Council. A. Reis and J. Roth (eds.). Washington, D.C.: National Academy Press, pp. 115-265.

Schriver, J.M. 1995. Human Behavior and the Social Environment. Toronto: Allyn \& Bacon.

Selby, D. 1993. "Global Education In The 1990's: Problems and Opportunities: Visions of 2001." Global Education, Vol. 1, No. 1, pp. 20-31.

Selby, D. 1987. Human Rights. London: Cambridge University Press.

Sherlock, J. and B. Hubert. 1989. Witness to Justice. Canada: Concan Inc.

Slaughter, R. 1988. "Futures." In Education for Peace: Issues, Principles and Practice in the Classroom. D. Hicks (ed.). London: Routledge, pp. 214-230.

Solokova, E. 1995. "Peace Education: From Person to Person." In Education and Human Development. H. Lofgren, H. (ed.). Sweden: Graphic Systems, pp. 344-346.

Sotela, S. 1994. "Forward." In Human Rights of Women. National and International Perspectives. R. Cook (ed.). Pennsylvania: University Of Pennsylvania Press, pp. i-v.

Suzuki, D. 1997. The Sacred Balance: Rediscovering Our Place in Nature. Vancouver: Greystone Books.

Sylvester, C. 1992. "Patriarchy, Peace and Women Warriors." In A Peace Reader. J. Fahey and R. Armstrong (eds.). New Jersey: Paulist Press, pp. 33-50.

Toh, S.H. 1987. "Education for Participation: Third World Perspectives." WCCI Forum, Vol. 1, No. 1, pp. 20-40. 
Toh, S.H., and V. Cawagas. 1990. Peaceful Theory and Practice in Values Education. Philippines: Phoenix Publishing House Inc.

Toh, S.H. and V. Cawagas. 1987. Peace Education A Framework for the Philippines. Quezon City: Phoeneix Press.

Torcyner, J. 2000. "Social Work and Globalization.” Social Work and Globalization, Special Issue. Vol. 2, No. 1, pp. 123-145.

Turner, F. 1999. Social Work Practice: A Canadian Perspective. Scarborough: Ontario.

UNESCO. 1995. UNESCO and a Culture of Peace: Promoting a Global Movement. Paris: UNESCO.

UNICEF 2000. Child Poverty in Rich Nations. New York: UNICEF Innocent Research Centre.

\section{UNICEF. 1995. State of The World's Children. New York: UNICEF}

Van Soest, D. and S. Bryant. 1995. "Violence Reconceptualized for Social Work: The Urban Dilemma.” Social Work, Vol. 40, No. 4, pp. 549-557.

Vellacot, J. 1988. "Hear the Women: Feminism and the Peace Movement.” In Implementing Peace Education. W. Brouwer and T. Carson (eds.). Edmonton, International Institute for Peace Education, pp. 103-122.

Yesufu A.O. 2000. Education For a Culture of Peace: Role of Women's Development Organizations. Unpublished doctoral thesis.

Young, K. 1993. Planning Development with Women. Hong Kong: Macmillan Press.

Ward, B. 1973. (ed). Day of Peace 1972. Publication Presented at 1973 Day of Peace Celebration. Rome: Vatican Press

Wells, L. 2000. "Social Workers and Homelessness: An Alberta Case Study.” Canadian Social Work, Volume 2, No. 2, pp. 118-131. 